\title{
Lymph Node Neoplasm
}

National Cancer Institute

\section{Source}

National Cancer Institute. Lymph Node Neoplasm. NCI Thesaurus. Code C35497.

A neoplasm involving the lymph node. 